\title{
Factors affecting the quality of anticoagulation with warfarin: experience of one cardiac centre
}

\author{
Tomasz Ciurus, Anna Cichocka-Radwan, Małgorzata Lelonek \\ Department of Cardiology, Medical University of Lodz, Lodz, Poland \\ Kardiochirurgia i Torakochirurgia Polska 2015; 12 (4): 334-340
}

\begin{abstract}
Introduction: The risk of complications in anticoagulation therapy can be reduced by maximising the percentage of time spent by the patient in the optimal therapeutic range (TTR). However, little is known about the predictors of anticoagulation control. The aim of this paper was to assess the quality of anticoagulant therapy in patients on warfarin and to identify the factors affecting its deterioration.

Material and methods: We studied 149 patients who required anticoagulant therapy with warfarin due to non-valvular atrial fibrillation and/or venous thromboembolism. Each patient underwent proper training regarding the implemented treatment and remained under constant medical care.

Results: The mean age of the patients was $68.8 \pm 12.6$ years, and $59 \%$ were male. A total of 2460 international normalised ratio (INR) measurements were collected during the 18-month period. The mean TTR in the studied cohort was $76 \pm 21 \%$, and the median was $80 \%$. The level at which high-quality anticoagulation was recorded for this study was based on TTR values above $80 \%$. Seventy-five patients with TTR $\geq 80 \%$ were included in the stable anticoagulation group (TTR $\geq 80 \%$ ); the remaining 74 patients constituted the unstable anticoagulation group (TTR < 80\%). According to multivariate stepwise regression analysis, the independent variables increasing the risk of deterioration of anticoagulation quality were: arterial hypertension (OR 2.74 [Cl 95\%: 1.06-7.10]; $p=0.038$ ), amiodarone therapy (OR 4.22 [Cl 95\%: 1.30-13.70]; $p=0.017$ ), and obesity (OR 1.11 [CI 95\%: 1.02-1.21]; $p=0.013$ ).

Conclusions: The presence of obesity, hypertension, or amiodarone therapy decreases the quality of anticoagulation with warfarin. High quality of anticoagulation can be achieved through proper monitoring and education of patients.

Key words: warfarin, TTR, unstable anticoagulation.
\end{abstract}

\section{Streszczenie}

Wstęp: Powikłania leczenia przeciwzakrzepowego można ograniczyć poprzez maksymalizację czasu przebywania pacjenta w optymalnym zakresie terapeutycznym (therapeutic range - TTR). Wciąż jednak niewiele wiadomo na temat czynników predykcyjnych leczenia przeciwzakrzepowego. Celem pracy była ocena jakości leczenia przeciwzakrzepowego u chorych przyjmujących warfarynę oraz identyfikacja czynników wpływających na jego pogorszenie.

Materiał i metody: Przebadano 149 pacjentów wymagających włączenia leczenia przeciwzakrzepowego za pomocą warfaryny z powodu niezastawkowego migotania przedsionków i/lub choroby zakrzepowo-zatorowej. Każdy pacjent przeszedł odpowiednie szkolenie odnośnie do wdrożonego leczenia i pozostawał pod stałą opieką lekarską.

Wyniki: Średni wiek badanej populacji wynosił 68,8 \pm 12,6 roku, a 59\% stanowili mężczyźni. W okresie 18 miesięcy obserwacji zebrano 2460 pomiarów INR (international normalised ratio; międzynarodowy współczynnik znormalizowany), na podstawie których dla każdego pacjenta wyliczono wartość TTR. Średnia TTR w badanej grupie wyniosła $76 \pm 21 \%$, mediana $80 \%$. Wysoka jakość leczenia przeciwzakrzepowego została oparta o wartość TTR powyżej $80 \%$. Siedemdziesięciu pięciu pacjentów z TTR $\geq 80 \%$ stanowiło grupę „stabilnej” antykoagulacji, pozostałych 74 pacjentów - grupę „niestabilnej” antykoagulacji z TTR < 80\%. Według analizy wieloczynnikowej regresji krokowej niezależnymi zmiennymi zwiększającymi ryzyko pogorszenia jakości leczenia przeciwzakrzepowego były: nadciśnienie tętnicze [OR 2,74 (95\% Cl: 1,06-7,10), $p=0,038$ ], leczenie amiodaronem [OR 4,22 (95\% Cl: 1,30-13,70); $p=0,017$ ] i otyłość [OR 1,11 (95\% Cl: 1,02-1,21), $p=0,013]$. W trakcie obserwacji nie stwierdzono występowania poważnych krwawień oraz powikłań zakrzepowo-zatorowych. Wnioski: Otyłość pacjenta, współwystępowanie nadciśnienia tętniczego i terapia amiodaronem mają wpływ na zmniejszenie jakości leczenia przeciwzakrzepowego za pomocą warfaryny. Właściwe monitorowanie i edukacja pacjentów pozwalają na uzyskanie wysokiej jakości leczenia przeciwzakrzepowego oraz ograniczenie występowania powikłań krwotocznych i zakrzepowo-zatorowych. Słowa kluczowe: warfaryna, TTR, leczenie przeciwzakrzepowe. 


\section{Introduction}

Despite the implementation of new anticoagulants, vitamin $\mathrm{K}$ antagonists (VKA) are the only treatment option for patients with prosthetic valves, valvular atrial fibrillation, or cardiac structural disease, as well as for the group of less affluent patients [1, 2]. In anticoagulation therapy using VKA, the lowest risk of complications is achieved by maximising the time in the optimum therapeutic range (TTR), with an international normalised ratio (INR) [3]. Ideally, the INR should be maintained in the therapeutic range most of the time, but many factors and types of drugs influence the attainment of this goal [4]. Patient-specific factors such as adherence to the therapeutic plan, appropriate dosing, and reliable INR control are also very important.

The rates of both major bleeding and mortality have been reported to be significantly higher in patients with TTR below $60 \%$ compared to those with TTR above 75\% [5]. Although TTR is routinely assessed, there is no consensus on acceptable TTR values. Most patients spend less than two thirds of their time within the therapeutic range [6]. The post hoc analysis of TTR values in the ACTIVE-W study suggested that, with TTR below 58\%, oral anticoagulation (OAC) showed little, if any, benefit over antiplatelet therapy in terms of preventing vascular events [7]. Inadequate anticoagulation should prompt interventions, such as increasing patient education and referring patients for specialist anticoagulation services.

The aim of this paper was to assess the quality of the anticoagulant therapy employed in patients treated with warfarin and to identify the factors affecting its deterioration.

\section{Material and methods}

The study was conducted on a population of 149 patients who had not been treated with anticoagulants and were admitted to the Department of Cardiology of the Medical University of Lodz in 2011-2012. The inclusion criterion was the indication for anticoagulant therapy in patients with non-valvular atrial fibrillation and/or venous thromboembolism. The exclusion criteria were: valvular heart disease, prosthetic heart valves, unstable arterial hypertension (> 160/110 mmHg), alcohol abuse, a serious incident of bleeding requiring blood transfusion, bleeding disorders, active peptic ulcers, liver disease (ALT > 3 times the upper reference level), and lack of consent for further contact.

Atrial fibrillation (AF) was diagnosed based on the resting electrocardiogram (ECG) and/or 24-hour Holter ECG monitoring. Venous thromboembolism (VTE) included both pulmonary embolism (PE) and deep vein thrombosis (DVT). The diagnosis of PE and/or DVT was based on relevant clinical presentations and the results of laboratory tests; it was confirmed by imaging studies such as Doppler ultrasound, echocardiography, computed tomography, and/or ventilation/perfusion scans. Only patients with objectively proven VTE were included in the study [8].

Atrial fibrillation patients with one or more stroke risk factors $\left(\mathrm{CHA}_{2} \mathrm{DS}_{2}\right.$-VASc score of $\left.\geq 1\right)$ were scheduled to re- ceive warfarin, after consideration of the patient's decision. The $\mathrm{CHA}_{2} \mathrm{DS}_{2}$-VASc score was calculated in accordance with the guidelines of the European Society of Cardiology [2].

The bleeding risk of our patients was assessed with the HAS-BLED score; one point was assigned for the presence of each of the following clinical features: hypertension, abnormal renal/liver function, stroke, bleeding history or predisposition (e.g. bleeding diathesis, anaemia), labile INR, older age (> 65 years), and drug therapy/alcohol intake [2]. Haemorrhages were classified as major or minor. Major bleeding was defined as any bleeding requiring the transfusion of at least two units of red blood cells or a whole blood equivalent, or bleeding associated with a variety of more severe outcomes. Minor bleeding was any non-major bleeding requiring the modification of the warfarin regimen (ecchymosis or haematoma, gastrointestinal bleeding, urinary bleeding, or bloody sputum).

The following information was collected:

- demographic: age, sex, place of residence,

- clinical: smoking, body mass index (BMI), comorbidities (arterial hypertension, diabetes mellitus, coronary artery disease, dyslipidaemia, renal failure, previous stroke, thromboembolic and bleeding events), and the use of drugs (antiplatelet drugs, amiodarone, $\beta$-blockers, calcium blockers, angiotensin converting enzyme inhibitors, sartans, statins, diuretics, digoxin, antibiotics, oral antidiabetic drugs),

- basic laboratory results: blood count, electrolytes, creatinine, glomerular filtration rate (GFR), glucose, lipids, liver enzymes, bilirubin, C-reactive protein, D-dimers, INR history.

The use of drugs (antiplatelet, antihypertensive, and antidiabetic) and diagnosis of particular diseases (hypertension, diabetes, lipid disorders, coronary artery disease) were consistent with the latest recommendations.

Warfarin dosing was managed by the cardiac team under INR control (therapeutic range 2.0-3.0). In case of any problems with the warfarin treatment, the patients had the opportunity to consult the cardiologist via phone at any time. The participants were informed about the diet limitations required in order to improve the effectiveness of the anticoagulant therapy. All the patients were usually started on a $10 \mathrm{mg}$ dose. During the first week of therapy, dose adjustments were made based on the warfarin induction algorithm described by Kovacs et al. [9]. International normalised ratios were routinely measured on days 3, 5, and 10 of therapy. Subsequently, INRs were measured at least once a month in the patient's residence. The results obtained during the first two weeks of therapy and the first week of treatment interruption were not included in further analysis. Throughout the follow-up, which lasted for 18 months, the patients were queried about compliance and adverse events with each INR measurement.

Therapeutic range was calculated using the Rosendaal method, which measures INR-specific person-time by incorporating the frequency of INR measurements and their actual values, and assuming that changes between consec- 
utive INR measurements are linear over time. Using this approach, a percentage of days during which the INR values are within a pre-specified range is obtained [10]. Therapeutic range was calculated for interpolated INR values within the recommended therapeutic range of 2.0 to 3.0.

Based on the median TTR, stable anticoagulation was precisely defined in our study as TTR $\geq 80 \%$. The TTR value

Tab. I. Characteristics of the study group

\begin{tabular}{|c|c|}
\hline & Total $(n=149)$ \\
\hline \multicolumn{2}{|l|}{ Follow-up (months) } \\
\hline Mean (standard deviation) & $16(4)$ \\
\hline \multicolumn{2}{|l|}{ Age } \\
\hline Mean (standard deviation) & $68(13)$ \\
\hline$\geq 75$ years & $55(37 \%)$ \\
\hline $65-74$ years & $38(25 \%)$ \\
\hline$<65$ years & $56(38 \%)$ \\
\hline Male (\%) & $88(59 \%)$ \\
\hline \multicolumn{2}{|l|}{ Medical history (\%) } \\
\hline Atrial fibrillation & 135 (91\%) \\
\hline Venous thromboembolism & $14(9 \%)$ \\
\hline Pulmonary embolism & $20(83 \%)$ \\
\hline Deep vein thrombosis & $4(17 \%)$ \\
\hline Heart failure & $41(27 \%)$ \\
\hline Hypertension (diagnosed) & $116(78 \%)$ \\
\hline Diabetes mellitus & $42(28 \%)$ \\
\hline Dyslipidaemia (treated) & $107(72 \%)$ \\
\hline Coronary artery disease & $62(42 \%)$ \\
\hline Myocardial infarction & $42(32 \%)$ \\
\hline Previous stroke & 19 (13\%) \\
\hline \multicolumn{2}{|l|}{ Medication (\%) } \\
\hline$\beta$-blockers & $131(88 \%)$ \\
\hline$\underline{\text { Statins }}$ & $117(79 \%)$ \\
\hline ACE inhibitors & $112(75 \%)$ \\
\hline Sartans & $12(8 \%)$ \\
\hline Aspirin & $56(38 \%)$ \\
\hline Clopidogrel & $30(20 \%)$ \\
\hline Amiodarone & $21(14 \%)$ \\
\hline \multicolumn{2}{|l|}{$\mathrm{CHA}_{2} \mathrm{DS}_{2}$-VASC } \\
\hline 1 & $7(5 \%)$ \\
\hline 2 & $20(13 \%)$ \\
\hline 3 & $43(29 \%)$ \\
\hline 4 & $33(22 \%)$ \\
\hline 5 & 19 (13\%) \\
\hline 6 & $13(9 \%)$ \\
\hline \multicolumn{2}{|l|}{ SAMe-TT2R2 } \\
\hline 0 & $8(5 \%)$ \\
\hline 1 & $78(53 \%)$ \\
\hline 2 & $54(36 \%)$ \\
\hline$>2$ & $9(6 \%)$ \\
\hline
\end{tabular}

was set at a high level compared with other studies [7]. The main purpose of this was to isolate a homogeneous group of patients with well-maintained anticoagulant therapy and then to search for the independent factors affecting the deterioration of anticoagulation quality.

Informed consent was obtained from all the participants, and access to their medical records was approved by the local Bioethics Committee.

The patients with TTR $\geq 80 \%$ were assigned to the stable anticoagulation group (Group I; $n=75$ ), while patients with TTR $<80 \%$ formed the unstable anticoagulation group (Group II; $n=74$ ).

\section{Statistical analysis}

Continuous variables were expressed as mean \pm standard deviation or median and interquartile range, while categorical variables were expressed as absolute numbers and percentages. For comparison between the groups (qualitative variables), $\chi^{2}$ or $\chi^{2}$ test with Yates' correction and $\chi^{2}$ test NW was used. The analysis of the quantitative variables employed Student's $t$-test (normal variable distribution in both groups) and the Mann-Whitney test (non-normal distribution). $P$ values $<0.05$ were considered statistically significant. For BMI set ROC curve and determined the optimal cut-off points that have been assigned the sensitivity, specificity, positive and negative predictive value (PPV and NPV). The analysis included odds ratios (OR) and 95\% confidence intervals $(95 \% \mathrm{Cl})$. Multivariate forward stepwise logistic regression analysis was undertaken to identify the independent risk factors for unstable anticoagulation. Candidate variables were entered into the model with a $p$-value less than 0.1. The analysis was performed using Statistica 10 and SPSS 20 software.

\section{Results}

A total of 149 patients met the study criteria. In further observation, we lost contact with three patients. Warfarin was included in all patients, of whom 136 (91\%) had atrial fibrillation (paroxysmal 43\%, persistent 38\%, permanent $19 \%$ ), and $13(9 \%)$ venous thromboembolism (83\% with pulmonary embolism). The most frequent co-morbidity was hypertension (78\%), followed by dyslipidaemia (71\%), coronary artery disease (42\%), and diabetes mellitus (28\%). Mean left ventricular ejection fraction (LVEF) was $51 \pm 12 \%$ (median 54\%). Twenty patients (13\%) had LVEF $\leq 35 \%$. For the studied population, the median of the $\mathrm{CHA}_{2} \mathrm{DS}_{2}$-VASC score was 3. Patient characteristics are listed in Table I.

A total of 2460 INR values were obtained during the 18-month period. Time in the TTR was calculated from a median of 17 INR values per patient (range: 12 to 24). The mean TTR in the cohort was $76 \pm 21 \%$. Only $18.9 \%$ of the patients had TTR below $60 \%$. During the follow-up, anticoagulant therapy was interrupted in 10 patients due to dental procedures (7 patients) and coronary angiography (3 patients).

Patients with unstable anticoagulation more often had hypertension $(p=0.01)$ and higher $\mathrm{BMI}(p=0.006)$. This 
group of patients also demonstrated a tendency for higher values of the $\mathrm{CHA}_{2} \mathrm{DS}_{2}$-VASc score and higher concentrations of high-sensitivity CRP (hSCRP); moreover, amiodarone therapy was administered more often to these patients (Table II).
The whole study group was at a low risk of bleeding, with a median HAS-BLED score of 1 (99.9\% of patients had HAS-BLED scores $\leq 2$, indicating low risk). During the follow-up, there were no major bleeds. Minor bleeding (upper respiratory 54\%, gastrointestinal $19 \%$, and urinary tract

Tab. II. Characteristics according to stable vs. unstable anticoagulation. The results are presented as $\%$, mean value \pm SD, and median with interquartile range (IQR)

\begin{tabular}{|c|c|c|c|}
\hline Total $(n=149)$ & $\begin{array}{l}\text { Stable anticoagulation } \\
(\mathrm{TTR} \geq 80 \%), n=75\end{array}$ & $\begin{array}{l}\text { Unstable anticoagulation } \\
\quad(\mathrm{TTR}<80 \%), n=74\end{array}$ & $p$ \\
\hline Age (years) & $67.6 \pm 12.3$ & $67.9 \pm 13.0$ & NS \\
\hline BMI $\left(\mathrm{kg} / \mathrm{m}^{2}\right)$ & $27.5 \pm 3.99$ & $29.8 \pm 5.32$ & 0.006 \\
\hline $\mathrm{CHA}_{2} \mathrm{DS}_{2}$-VASc score & $3.1 \pm 1.6$ & $3.6 \pm 1.6$ & 0.089 \\
\hline HAS-BLED & $1.0 \pm 0.84$ & $1.2 \pm 0.7$ & 0.078 \\
\hline Ejection fraction (\%) & $51.6 \pm 12.0$ & $51.2 \pm 13.8$ & NS \\
\hline Dose of warfarin daily (mg) & $4.7 \pm 1.26$ & $4.6 \pm 1.76$ & NS \\
\hline Dose of warfarin weekly (mg) & $32.6 \pm 9.01$ & $31.9 \pm 12.3$ & NS \\
\hline \multicolumn{4}{|l|}{ Laboratory results } \\
\hline Haemoglobin $(\mathrm{g} / \mathrm{dl})^{*}$ & $13.9(12.8-15.2)$ & $14(12.8-14.8)$ & NS \\
\hline Platelets $\left(10^{3} / \mu \mathrm{l}\right)$ & $215.7 \pm 92.9$ & $212.8 \pm 67.5$ & NS \\
\hline Sodium $(\mathrm{mmol} / \mathrm{l})$ & $138 \pm 2.35$ & $136 \pm 16.3$ & NS \\
\hline Potassium (mmol/l) & $4.31 \pm 0.55$ & $4.23 \pm 0.48$ & NS \\
\hline Urea $(\mathrm{mg} / \mathrm{dl})^{*}$ & $6.55(4.8-7.9)$ & $6.63 \pm 2.83$ & NS \\
\hline GFR $\left(\mathrm{ml} / \mathrm{min} / 1.72 \mathrm{~m}^{2}\right)$ & $87.9 \pm 34.1$ & $87.7 \pm 34.6$ & NS \\
\hline Glucose $(\mathrm{mmol} / \mathrm{l})$ & $5.9 \pm 1.29$ & $5.8 \pm 1.26$ & NS \\
\hline $\mathrm{TCh}(\mathrm{mmol} / \mathrm{l})^{*}$ & $4.65(3.75-5.25)$ & $4.5 \pm 1.18$ & NS \\
\hline $\mathrm{LDL}(\mathrm{mmol} / \mathrm{l})$ & $2.6 \pm 1.14$ & $2.4 \pm 0.99$ & NS \\
\hline $\mathrm{HDL}(\mathrm{mmol} / \mathrm{l})^{*}$ & $1.31(1.07-1.48)$ & $1.4 \pm 0.71$ & NS \\
\hline $\mathrm{TG}(\mathrm{mmol} / \mathrm{l})$ & $1.3 \pm 0.57$ & $1.4 \pm 0.6$ & NS \\
\hline $\operatorname{ALT}(I U / I)$ & $29.2 \pm 17.4$ & $26.4 \pm 13.7$ & NS \\
\hline AST (IU/I) & $27.8 \pm 12.7$ & $25.5 \pm 9.1$ & NS \\
\hline hsCRP (mg/dl) & $4.0 \pm 5.9$ & $5.7 \pm 6.1$ & 0.081 \\
\hline Fibrinogen $(\mathrm{g} / \mathrm{l})$ & $3.8 \pm 1.5$ & $4.12 \pm 1.6$ & NS \\
\hline D-dimers $(\mu \mathrm{g} / \mathrm{ml})$ & $1.02 \pm 1.4$ & $1.01 \pm 1.4$ & NS \\
\hline \multicolumn{4}{|l|}{ Clinical data (\%) } \\
\hline Arterial hypertension & 69 & 86 & 0.01 \\
\hline Previous stroke & 12 & 13 & NS \\
\hline Coronary artery disease & 53 & 50 & NS \\
\hline Heart failure & 12 & 8 & NS \\
\hline Diabetes & 24 & 32 & NS \\
\hline Dyslipidaemia & 68 & 75 & NS \\
\hline Bleedings & 6.7 & 16.2 & 0.06 \\
\hline Interruption of anticoagulant therapy (\%) & 6.6 & 6.8 & NS \\
\hline \multicolumn{4}{|l|}{ Medications (\%) } \\
\hline Aspirin & 36 & 39 & NS \\
\hline Clopidogrel & 24 & 16 & NS \\
\hline Amiodarone & 9.3 & 18.9 & 0.09 \\
\hline Antibiotics & 5.3 & 5.4 & NS \\
\hline
\end{tabular}

BMI - body mass index, GFR - glomerular filtration rate, TCh - total cholesterol, LDL - low density lipoproteins, HDL - high density lipoproteins, TG - triglycerides, ALT - alanine aminotransferase, AST - aspartate aminotransferase, hSCRP - high sensitivity C-reactive protein, CAD - coronary artery disease, SD - standard deviation, IQR - interquartile range, *non-normal data 
Tab. III. Predictors of unstable anticoagulation in multivariate logistic regression analysis

\begin{tabular}{lcc} 
& OR $(95 \% \mathrm{Cl})$ & $p$ \\
\hline Arterial hypertension & $2.74(1.06-7.10)$ & 0.038 \\
\hline Amiodarone therapy & $4.22(1.30-13.70)$ & 0.017 \\
\hline $\mathrm{BMI}\left(\mathrm{kg} / \mathrm{m}^{2}\right)$ & $1.11(1.02-1.21)$ & 0.013 \\
\hline $\mathrm{Cl}$ - confidence interval, OR - odds ratio, BMI - body mass index &
\end{tabular}

$27 \%)$ was observed in only 17 patients (11.4\%), with no statistically significant difference between the study groups $(p=0.06)$.

No thromboembolic complications were recorded during the 18 months of follow-up.

According to multivariate stepwise regression analysis, the independent variables for increased risk of worse anticoagulation quality were arterial hypertension, amiodarone therapy, and obesity (Table III). From the ROC curve, the cut-off point value for $\mathrm{BMI} \geq 27.75 \mathrm{~kg} / \mathrm{m}^{2}$ was determined $(\mathrm{AUC}=0.63 ; \mathrm{OR}=2.33,95 \% \mathrm{Cl}: 0.54-0.72, p=0.006)$ with sensitivity of $60.8 \%$, specificity of $60 \%$, PPV $=60 \%$, and NPV $=60.8 \%$ (Fig. 1).

\section{Discussion}

The present study revealed factors associated with worse quality of anticoagulation in patients treated with warfarin under the supervision of an experienced team. Coexistence of arterial hypertension, obesity, and amiodarone therapy was associated with lower likelihood of staying within the target INR range.

In the studied population, the strongest independent predictor for inferior anticoagulation quality was amiodarone therapy (OR 4.22, $p=0.017$ ). Similar results were observed in AF patients treated with warfarin, who were enrolled in the AFFIRM trial [11]. Treatment with amiodarone $(\beta=-0.03, p=0.05)$, the main rhythm-control drug in AFFIRM, had a negative effect on TTR [10]. However, the effect of amiodarone on INR variability had been known before. Amiodarone inhibits the hepatic metabolism of warfarin, potentiating its anticoagulant effect and resulting in INR prolongation and increased risk of bleeding $[12,13]$. Despite intensive monitoring and education of patients, amiodarone had a negative impact on the quality of anticoagulation.

In our study, worse quality of anticoagulation was associated with BMI above 27.75. Thus, we revealed that "unstable" anticoagulation might result from lower BMI values than those described by Apostolakis et al. (BMI > 30; $p=$ 0.02 ) [11]. The obtained BMI has a relatively low discriminatory value, mainly due to the small number of patients. The impact of obesity on the quality of anticoagulation may be related to the differences in the pharmacokinetic parameters of drug metabolism [14]. Similarly to our results, in the study of Apostolakis et al., arterial hypertension $(\beta=-0.04$, $p<0.0001)$ was also associated with lower TTR [11]. In contrast, this relationship was not confirmed in the Veterans AffaiRs Study to Improve Anticoagulation (VARIA) [15]. Nevertheless, the impact of hypertension on the quality of

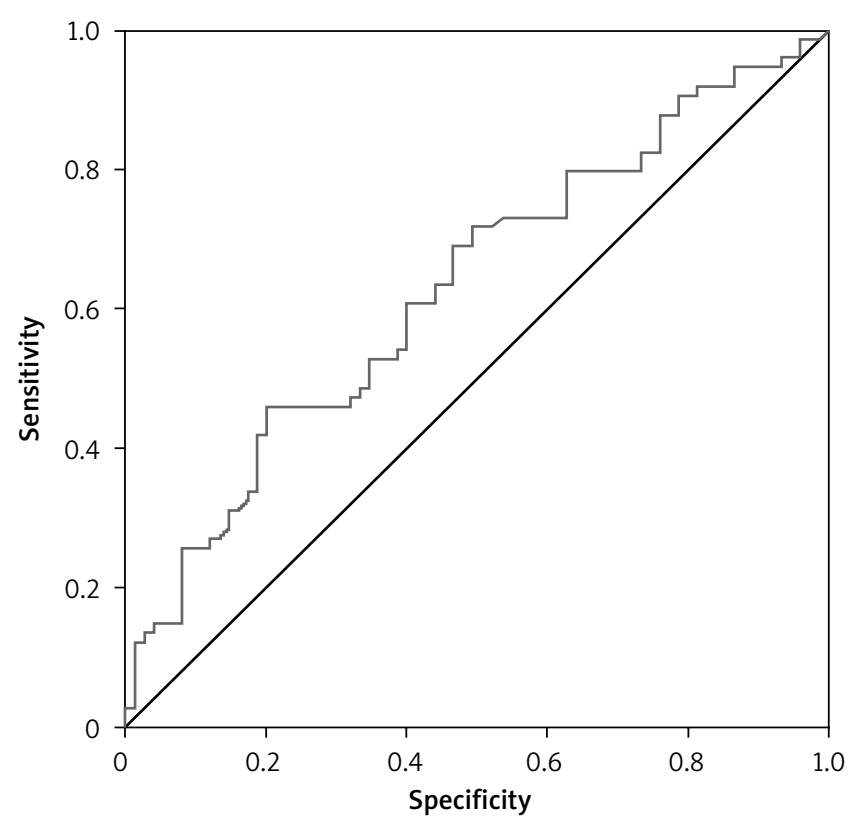

Fig. 1. ROC curve for body mass index (BMI)

anticoagulation remains unknown. The possible mechanisms may be associated with the drug interactions. However, our study demonstrated no statistically significant differences between the drugs used by the studied patients. In contrast to our results, patients with diabetes, peripheral arterial disease, heart failure, previous stroke, or myocardial infarction were described as more likely to have lower values of TTR [11].

Other factors associated with unstable anticoagulation, such as age, sex, race, or smoking, have also been described. The results regarding age and its association with anticoagulation control are conflicting. The research of Melamed et al. showed that patients over 70 years old experienced worse quality of anticoagulation [16]. Another analysis presented in the Cardiovascular Research Network WAVE Study found that age $>50$ years was a predictor of higher TTR [17], whereas we found no relationship between age and unstable anticoagulation. It is known that achieving good control with warfarin in women is more difficult, but the precise reasons for this remain unclear $[6,17,18]$. Furthermore, women are known to be at a higher risk of AF-related stroke regardless of warfarin use, which could be related to poorer anticoagulation control in women. In our study, the gender relationship was not confirmed.

Knowledge of demographic and clinical risk factors is crucial in the management of anticoagulation. One of the first attempts to create a simple risk scale for the assessment of unstable anticoagulation is the SAMe-TT $R_{2}$ score, in which 1 point is assigned for sex (female), age (less than 60 years), medical history, and treatment (rhythm control), while 2 points are assigned for tobacco use and race (nonCaucasian) [11]. Medical history was defined as more than two of the following comorbidities: hypertension, diabetes, coronary artery disease/myocardial infarction, peripheral arterial disease, congestive heart failure, previous stroke, pulmonary disease, and hepatic or renal disease [11]. Based 
on these data, patients with SAMe- $\mathrm{TT}_{2} \mathrm{R}_{2}$ score $0-1$ are at a significantly lower risk of unstable anticoagulation compared to patients with $S A M e-T T_{2} R_{2}$ score $\geq 2$ [11]; the latter might not be suitable candidates for VKAs and would benefit more from novel oral anticoagulants. Based on the SAMe- $\mathrm{TT}_{2} \mathrm{R}_{2}$ score, 63 patients in the studied population $(42 \%)$ were at a high risk of unstable anticoagulation. That result was consistent with the criterion of TTR $<80 \%$ used in the present study.

The lowest risk of anticoagulation with VKA is achieved by maximising the time spent in the optimum TTR, with an INR. Multiple studies have demonstrated that mean (or median) TTR predicts stroke and bleeding outcomes in AF populations. Therapeutic range is easily interpreted, and this method assumes that INR values vary linearly between two measurements. A limitation of the TTR method is that the extent to which INR values fluctuate over time and the timing and severity of fluctuations are not measured [19]. A search is ongoing for methods that would better describe INR variability in order to improve VKA therapy. Although TTR is routinely assessed, there is a lack of consensus on the acceptable TTR values. A significant benefit from VKA therapy derived patients treated at centres that achieved a TTR above $65 \%[5,18]$. Values above $75 \%$ are considered to represent excellent anticoagulation control. The mean TTR in our study (76\%) was higher than that achieved in clinical trials (66.4\%) according to a recent meta-analysis [20]. This result was achieved despite the high prevalence of arterial hypertension, coronary artery disease, and diabetes mellitus. Only $18.9 \%$ of the patients had TTR below $60 \%$. Similarly, high values of TTR were observed in patients from Scandinavian countries [21-23]. The high value of TTR in study group testifies to the excellent care provided by an experienced cardiac team. Therefore, the TTR cut-off point for the distribution of the study groups was set at such a high level.

During follow-up, we recorded only minor bleeds despite the frequent use of antiplatelet drugs. This may be due to the high quality of anticoagulation therapy in our patients. Alternatively, it may be stem from the short period of observation.

Evaluation of current patient knowledge regarding oral anticoagulation therapy is the first step in improving the quality of anticoagulation therapy and patient care [16]. Studies show that some patients lack basic knowledge concerning anticoagulation therapy. The knowledge gaps were most prominent in the domains of dietary interactions, followed by drug interactions, adverse effects, and PT/INR monitoring [24]. These limitations were restricted to a minimum in our study because constant care was provided to each patient by an experienced team.

In our study, patient education was limited to an adequate explanation of the treatment and its restrictions with regard to the use of drugs and diet. In addition, the dose of warfarin was modified, usually on the same day that the patient received the result of the INR by the cardiologist from the cardiac centre (the first author of the study).
This allowed us to reduce the incidence of complications to a minimum.

High-quality anticoagulation with warfarin is possible provided that education is offered to the patients, their INR levels are closely monitored for dose adjustment, and regular contact is maintained with coagulation services. Prior studies have documented that anticoagulation units improve patient outcomes, with patients spending more TTR and sustaining fewer complications [25-27], as was the case with our patients. Thus, more trials are needed to examine the impact of interventions on anticoagulation control and the mechanisms conditioning their success.

\section{Limitations}

There are several limitations to this study. The study group consisted of a relatively small number of patients, and the period of follow-up was short in comparison with large registers. We did not include some factors that contribute to variability in anticoagulation stability, especially genetic factors. Another limitation is our reliance on medical records for data collection, which is dependent on patient self-reporting. However, the use of a standardised interview sheet minimised inconsistencies in the clinical data.

A further limitation was that the patients performed the measurements in their place of residence, and we were not able to verify INR accuracy and inter-laboratory precision.

We did not have data on the results of blood cell counts to exclude occult bleeding.

The value of stable TTR ( $\geq 80 \%$ ) was set at a high level. This created difficulties in comparing our results with other studies. The use of lower TTR thresholds resulted in obtaining a statistically small study group. Therefore, the median value of TTR was used as a cut-off point for further statistical analysis.

The final important issue was the imperfection of the TTR method in assessing the quality of anticoagulation as described earlier in the article.

\section{Conclusions}

The presence of obesity, hypertension, and amiodarone therapy in our patients was associated with worse quality of anticoagulation. Despite the presence of these comorbidities, we achieved high quality of the therapy, primarily through adequate control and patient education. Therefore should arise clinical centres, involved in the control of patients on oral anticoagulation.

\section{Disclosure}

Authors report no conflict of interest.

\section{References}

1. Joint Task Force on the Management of Valvular Heart Disease of the European Society of Cardiology (ESC); European Association for Cardio-Thoracic Surgery (EACTS), Vahanian A, Alfieri O, Andreotti F, Antunes MJ, Barón-Esquivias G, Baumgartner H, Borger MA, Carrel TP, De Bonis M, Evangelista A, Falk V, lung B, Lancellotti P, Pierard L, Price S, Schäfers HJ, Schuler G, Stepinska J, Swedberg K, Takkenberg J, Von Oppell UO, Windecker S, Zamorano JL, 
Zembala M. Guidelines on the management of valvular heart disease (version 2012). Eur Heart J 2012; 33: 2451-2496.

2. Camm AJ, Lip GY, De Caterina R, Savelieva I, Atar D, Hohnloser SH, Hindricks G, Kirchhof P; ESC Committee for Practice Guidelines (CPG). 2012 focused update of the ESC Guidelines for the management of atrial fibrillation: an update of the 2010 ESC Guidelines for the management of atrial fibrillation. Developed with the special contribution of the European Heart Rhythm Association. Eur Heart J 2012; 33: 2719-2747.

3. Mant J, Hobbs FD, Fletcher K, Roalfe A, Fitzmaurice D, Lip GY, Murray E; BAFTA investigators; Midland Research Practices Network (MidReC). Warfarin versus aspirin for stroke prevention in an elderly community population with atrial fibrillation (the Birmingham Atrial Fibrillation Treatment of the Aged Study, BAFTA): a randomised controlled trial. Lancet 2007; 370: 493-503.

4. Undas A, Cieśla-Dul M, Zółciński M, Tracz W. Switching from acenocoumarol to warfarin in patients with unstable anticoagulation and its effect on anticoagulation control. Pol Arch Med Wewn 2009; 119: 360-365.

5. White HD, Gruber M, Feyzi J, Kaatz S, Tse HF, Husted S, Albers GW. Comparison of outcomes among patients randomized to warfarin therapy according to anticoagulant control: results from SPORTIF III and V. Arch Intern Med 2007; 167: 239-245.

6. Rose AJ, Ozonoff A, Henault LE, Hylek EM. Warfarin for atrial fibrillation in community-based practise. J Thromb Haemost 2008; 6: 1647-1654.

7. Connolly SJ, Pogue J, Eikelboom J, Flaker G, Commerford P, Franzosi MG, et al. Benefit of oral anticoagulant over antiplatelet therapy in AF depends on the quality of the INR control achieved as measured by time in therapeutic range. Circulation 2008; 118: 2029-2037.

8. Torbicki A, Perrier A, Konstantinides S, Agnelli G, Galiè N, Pruszczyk P, et al. ESC Committee for Practice Guidelines (CPG). Guidelines on the diagnosis and management of acute pulmonary embolism: the Task Force for the Diagnosis and Management of Acute Pulmonary Embolism of the European Society of Cardiology (ESC). Eur Heart J 2008; 29: 2276-2315.

9. Kovacs MJ, Rodger M, Anderson DR, Morrow B, Kells G, Kovacs J, Boyle E, Wells PS. Comparison of 10-mg and 5-mg warfarin initiation nomograms together with low-molecular-weight heparin for outpatient treatment of acute venous thromboembolism. A randomized, double-blind, controlled trial. Ann Intern Med 2003; 138: 714-719.

10. Rosendaal FR, Cannegieter SC, Van der Meer FJ, Briet E. A method to determine the optimal intensity of oral anticoagulant therapy. Thromb Haemost 1993; 69: 236-239.

11. Apostolakis S, Sullivan RM, Olshansky B, Lip GY. Factors affecting quality of anticoagulation control amongst atrial fibrillation patients on warfarin: The SAMe-TT2R2 (Sex female, Age less than 60, Medical history, Treatment strategy [rhythm control], Tobacco use [doubled], Race [doubled] score. Chest 2013; 144: 1555-1563.

12. McDonald MG, Au NT, Wittkowsky AK, Rettie AE. Warfarin-amiodarone drug-drug interactions: determination of $[\mathrm{I}](\mathrm{U}) / \mathrm{K}(\mathrm{I}, \mathrm{u})$ for amiodarone and its plasma metabolites. Clin Pharmacol Ther 2012; 91: 709-717.
13. Sanoski CA, Bauman JL. Clinical observations with the amiodarone/warfarin interaction: dosing relationships with long-term therapy. Chest 2002; 121: 19-23.

14. Hanley MJ, Abernethy DR, Greenblatt DJ. Effect of obesity on the pharmacokinetics of drugs in humans. Clinical Pharmacokinetics 2010; 49: 71-87.

15. Rose AJ, Hylek EM, Ozonoff A, Ash AS, Reisman JI, Berlowitz DR. Patient characteristics associated with oral anticoagulation control: results of the Veterans AffaiRs Study to Improve Anticoagulation (VARIA). J Thromb Haemost 2010; 8: 2182-2191.

16. Melamed OC, Horowitz G, Elhayany A, Vinker S. Quality of anticoagulation control among patients with atrial fibrillation. Am J Manag Care 2011; 17: 232-237.

17. Go AS, Fan D, Chang Y, Chan J, Chan J, Lieu TA, Magid DJ, et al. Quality of anticoagulation management in atrial fibrillation and venous thromboembolism: the CVRN WAVE study. Circulation 2010; 122: A14870 (Abstract).

18. Morgan CL, McEwan P, Tukiendorf A, Robinson PA, Clemens A, Plumb JM. Warfarin treatment in patients with atrial fibrillation: observing outcomes associated with varying levels of INR control. Thromb Res 2009; 124: 37-41.

19. Van Den Ham HA, Klungel OH, Leufkens HG, Van Staa TP. The patterns of anticoagulation control and the risk of stroke, bleeding and mortality in patients with non-valvular atrial fibrillation. J Thromb Haemost 2013; 11: 107-115.

20. Baker WL, Cios DA, Sander SD, Coleman CI. Meta-analysis to assess the quality of warfarin control in atrial fibrillation patients in the United States. J Manag Care Pharm 2009; 15: 244-252.

21. Hallinen T, Soini EJ, Asseburg C, Kuosmanen P, Laakkonen A. Warfarin treatment among Finnish patients with atrial fibrillation: retrospective registry study based on primary healthcare data. BMJ Open 2014; 4: e004071.

22. Nielsen PB, Lundbye-Christensen S, Rasmussen LH, Larsen TB. Improvement of anticoagulant treatment using a dynamic decision support algorithm: A Danish Cohort study. Thromb Res 2014; 133: 375-379.

23. Sjögren V, Grzymala-Lubanski B, Renlund H, Friberg L, Lip GY, Svensson PJ, Själander A. Safety and efficacy of well managed warfarin. A report from the Swedish quality register Auricula. Thromb Haemost 2015; 26: 113.

24. Alphonsa A, Sharma KK, Sharma G, Bhatia R. Knowledge Regarding Oral Anticoagulation Therapy among Patients with Stroke and Those at High Risk of Thromboembolic Events. J Stroke Cerebrovasc Dis 2015: S1052-3057.

25. Masaki N, Suzuki M, Matsumura A, Maruyama Y, Hashimoto Y. Quality of warfarin control affects the incidence of stroke in elderly patients with atrial fibrillation. Intern Med 2010; 49: 1711-1716.

26. Witt DM, Sadler MA, Shanahan RL, Mazzoli G, Tillman DJ. Effect of a centralized clinical pharmacy anticoagulation service on the outcomes of anticoagulation therapy. Chest 2005; 127: 1515-1522.

27. Bond CA, Raehl CL. Pharmacist-provided anticoagulation management in United States hospitals: death rates, length of stay, medicare charges, bleeding complications, and transfusions. Pharmacotherapy 2004; 24: 953963. 